\title{
A Review on Rockburst as a Serious Safety Problem in Deep Underground Mines and other Excavation Projects
}

\author{
Evariste Murwanashyaka ${ }^{1}$, Xuefeng $\mathrm{Li}^{1}$ \\ ${ }^{1}$ College of Resources, Environment and Materials_ Guangxi University, \\ Nanning, Guangxi 530004, People's Republic of China.
}

\begin{abstract}
The previous research has found that, rockburst is a ground stress related problem which is likely to occur in deep underground mines or other excavation projects as the mining or excavation depth increase significantly. From this point of view, in order to initiate a research in deep underground engineering, the Authors have reviewed rockburst as a serious safety problem in deep underground mines and other excavations around the world. As the main objectives of this paper, the review was conducted for a thorough understanding of rockburst problem to arouse the Authors' great deal of interest to go through a detailed research on rockburst and other dynamic disasters in deep underground engineering. In such circumstance, the meaning and main causes, status, characteristics, different classification, and the main negative effects of rockburst and its control methods were discussed to achieve the objectives of this paper.
\end{abstract}

Keywords: Deep underground mine; Rockburst; Mining depth; Ground stres

\section{INTRODUCTION}

It is obviously known that mineral deposits are indispensable materials for improving the development of a national economy ( $\mathrm{Li}$ and Murwanashyaka, 2019). With the increasing demand of social and economic development of a nation, and the progress of mining engineering technology, the exploitation of mineral deposits is constantly developing to greater depth, which is the inevitable trend of future development (GONG, 2017; 2018). Along with this development of national economy, the demand for non-metal and metal resources is increasing, shallow resources have been gradually exhausted, forcing most of the mines to initiate deep deposit mining (Li and Murwanashyaka, 2019). As positively related, the depth of mining increases with the increase of ground stress (Kouame et al., 2017; Liu and Wang, 2018), refer to the Fig1. With this deep deposit mining and high concentration of ground stress, the subsequent frequency of rock bursts occurrence increases consequently, which strongly hinder the safe and efficient mining (He et al., 2012; Kaiser and Cai, 2012; Chen et al., 2012; Cai, 2016; Xia et al., 2017; Sengani and Zvarivadza, 2017; Kouame et al., 2017).

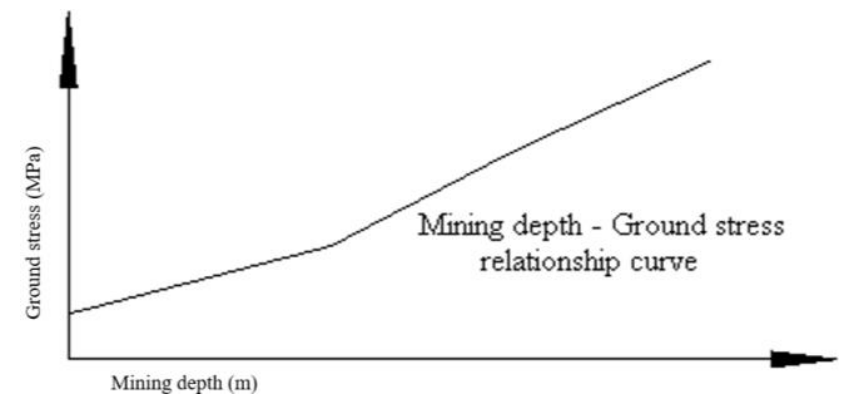

Fig 1. Diagram presenting Mining depth and Ground stress Relationship

The deep mining has been worldwidely initiated, According to Hudyma and Potvin (2010), Some abroad mines are working at and greater than $1000 \mathrm{~m}$ below the ground surface level, where rock bursts hazards highly tend to occur. For example the deepest mines in Australia are recently working between $1000 \mathrm{~m}$ and $1650 \mathrm{~m}$ below the ground surface level; The deepest mines in Canada are working between $1500 \mathrm{~m}$ and $2500 \mathrm{~m}$ of depth; and the first wold's country with deepest mines vary from $3000 \mathrm{~m}$ to $3800 \mathrm{~m}$ is South Africa (Liu et al., 2018); India Kolar gold mining area has 3 gold mines with greater than $2400 \mathrm{~m}$ of depth (Wen et al., 2016); In Russia, The depth of mining in iron ore field of Krivoy Rog is currently $910 \mathrm{~m}$ which is explored up to $1570 \mathrm{~m}$, and it is planned to reach around $2500 \mathrm{~m}$ below ground surface (Wen et al., 2016).

In recent years, several metal mines in China have been initiated deep mining exceeding $1000 \mathrm{~m}$ below the ground surface level (Liu et al., 2018; Liu and Wang, 2018). Some examples of deep metal mines in China include Hongtoushan Copper Mine in Fushun, Liaoning province and Shizishan copper mine in Tongling, Anhui province have reached greater than 1000m of depth (Liu and Wang, 2018); Dongguashan Copper Mine in Anhui province has also reached greater than $1000 \mathrm{~m}$ of depth (Shao et al., 2016; Liu et al., 2018; Liu and Wang, 2018); Jiapigou Gold Mine in Jilin province, North eastern China, has extended to about $1050 \mathrm{~m}$ (Zeng et al., 2014; Meng et al., 2016; Yang et al., 2017); and Xiangxi Gold Mine in Hunan province has been exploited to about 1000m below the ground level (Yang et al., 1998); Shouwangfen Copper Mine in Chengde, Hebei province, has also reached greater than $1000 \mathrm{~m}$ of depth (Chen et al., 2007); Fankou Lead-Zinc Mine in Guangdong province at $1000 \mathrm{~m}$ below ground level (zhang et al., 2014); Jinchuan Nickel Mine in Jinchang, Gansu, is working at 1100m (Yuan et al., 2013; Yang et al., 2017); Rushan Gold Mine in Weihai, Shandong 
province, has been also exploited to about $1000 \mathrm{~m}$ of depth (Fan et al., 2006); Ashele copper mine greater than 1200m, Huize lead zinc mine greater than 1600m (Liu and Feng, 2017); The shaft deepth of Yanxin gold mine, Sishanling iron mine, Sashandao gold mine, and Guilaizhuang gold mine already reached 1500, 1500, 1200 and $1000 \mathrm{~m}$ of depth, respectively (Liu and Feng, 2017). Due the increase of mining depth and subsequent ground stress, some of the abovementioned mines have undergone rockburst problem. This review focuses on rockburst prone mines countries such China, South Africa, Canada, USA, Australia and some others; and deep tunnels excavation projects in china.

\section{LITERATURES ON ROCKBURST IN CHINA AND OUT OF CHINA}

\subsection{Meaning and main causes of rockburst.}

Rockburst are seismic events triggered by deep deposits exploitation in which the rocks fail abruptly and brittlely with high degree of damage after getting strained above their ultimate elasticity. According to Larsson (2004), Kabwe and Wang (2015), a rockburst is the exploitation induced seismic event that affects and cause destruction to excavations in the rock. Vennes and Mitri (2017) defined rock bursts as seismic events where the rock suddenly and violently fails in a brittle way after being strained beyond its elastic limit. Previous research results by Mao and Zhang (1996) show that, the rockburst is due to the failure of rock mass balance in high stress zone, and the stress concentration in rock mass causes brittle failure of rock mass and dynamic instability accompanied by energy release. The occurrence of rock burst is controlled by stress conditions, that is to say, the stress in orebody and surrounding rock where rock burst tend to occur should reach the ultimate stress state.

In general, rockburst can be caused by a single factor or multiple factors. Single factor is when rockburst is caused by one factor, and multiple factors is when rockburst is caused by more than one factors. In general, during deep mining, rockburst is triggered by external causes (in case of opening operation) and internal causes (linked to rock mass characteristics). Based on influence of multiple coupled geological factors such as geological structure, rock strata formation, physical and mechanical properties of rock mass, exploitation method and shape of opening, blasting operation, ground water, ground or in-situ stress state and the distribution rule of the catastrophic state of rock mass in deep deposit, one or a combination of some of the above mentioned factors can cause rock burst and other dynamic disasters in deep metal mines.

\subsection{Rock Burst in Chinese Mine}

Historically, in 1933, the first rock burst occurred in Shengli Mine, Fushun in Liaoning province.

At that time, the mining depth was only $200 \mathrm{~m}$, With the increase of depth of mining and mining ratio, rock burst had occurred in the mine many times. In 1960, there were only 6 mines with rock burst in China. Up to 1990, only 58 coal mines had undergone rock burst, in recent years, more than 100 coal mines had undergone rock burst (Shi et al., 2005). More than 20 metal mines have also undergone rock burst. The rockburst problem in Chinese mines is more pronounced in North-eastern, Eastern, and South-eastern part of china, as shown on Fig 2. Around $97 \%$ of rockburst historical cases are said to be in this eastern part of China.

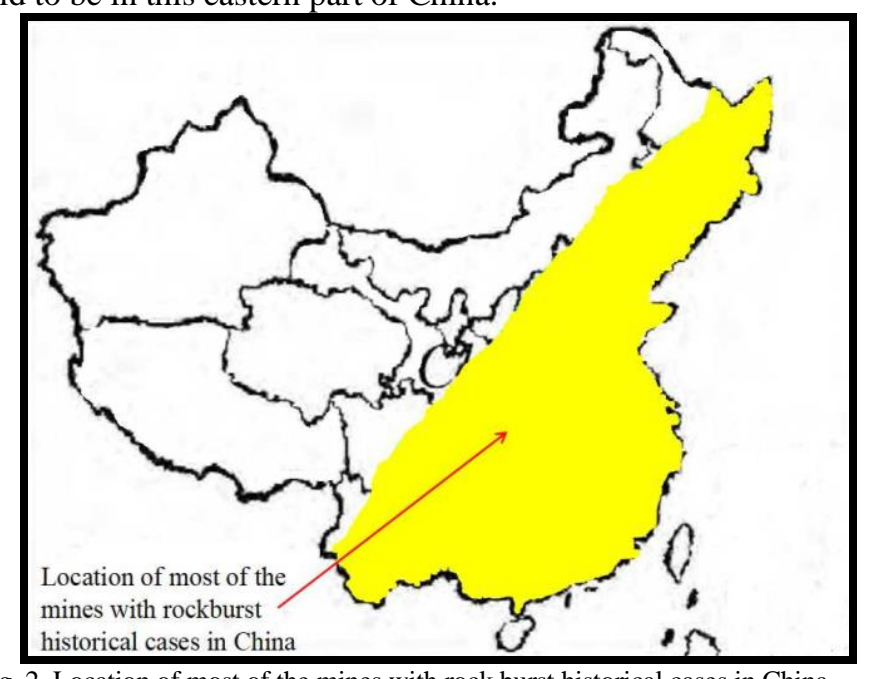

Fig. 2. Location of most of the mines with rock burst historical cases in China

\subsubsection{In Chinese Metal Mines}

Due to the fact that, the Chinese shallow metal resources have been gradually exhausted, therefore, some metal mines have been initiated deep mining exceeding $1000 \mathrm{~m}$ below the ground surface level (Liu et al., 2018; Liu and Wang, 2018). This deep deposit mining lead to the high concentration of ground stress, then subsequent frequency of rock bursts occurrence increases consequently (He et al., 2012; Kaiser and Cai, 2012; Chen et al., 2012; Cai, 2016; Feng et al., 2017; Sengani and Zvarivadza, 2017; Kouame et al., 2017). From 2011 to 2013, the 17 burst cases have occurred in Zhazixi Antimony Mine (Ma et al., 2018), in 1996-1999, Dongguashan copper mine had undergone several rockbursts; Erdaogou gold mine in April 2006, and Linglong gold mine in January 2013, had also undergone rockbursts; In Hongtoushan copper mine, Fushun, Liaoning, one case occurred on $18^{\text {th }}$, May 1999, and other on $8^{\text {th }}$, Jan 2005 (Liu and Wang, 2017; Liu and Feng, 2017); From 2004 to 2005, the 18 cases have occurred in Yinxi Gold Mine (ZHANG and WANG, 2007); From 2001 to 2007, several rockburst hazards were reported in China, with around 16000 casualties (Zhou et al. 2016).

\subsubsection{In Chinese Coal Mines}

In China, Rockburst is more pronounced in coal mines than in metal mines. It is a significant safety and economic problem in deep underground coal mines. There are more than 50 coal mines which are working at and greater than one thousand meters below the ground surface level. In 1985, the rock burst happened in 32 coal mines, up to 2012, more than 140 coal mines had undergone rock burst problem. Between the year of 2006 and 2013, rockburst happened 35 times in more than 9 coal mines, with 300 deaths, and the above 1000 injured miners (Wen et al., 2016). Below are the possible factors for coal bursting in Chinese coal mines:

Rockburst due to depth of coal seams exploitation: Recently, the shallow coal seams have been gradually exhausted, forcing most of the mines to initiate deep coal seams mining. As positively related, the depth of mining increases with ground stress (Kouame et al., 2017; Liu and 
Wang, 2018). With this deep mining and high concentration of ground stress, the subsequent frequency of rock bursts occurrence increases consequently (He et al., 2012; Kaiser and Cai, 2012; Chen et al., 2012; Cai, 2016; Feng et al., 2017; Sengani and Zvarivadza, 2017; Kouame et al., 2017).

Coal seam Compressive rock burst: is the rock burst caused by the instability of coal seam under compression, including gravity and horizontal tectonic stress, which mostly occurs in thick coal seam mining face and mining roadway. It is the dynamic phenomenon of instability and failure of coalrock structure under the action of compressive load.

Roof tensile rock burst: is the rock burst caused by the tensile instability of roof rock. The roof rock burst mostly occurs in the hard, compact, complete and thick rock mass of the working face roof. With the mining working face, a large area of goaf roof is formed. When the hanging roof area of the goaf reaches a certain value, the tensile instability of the roof rock causes the Roof tensile rock burst.

Fault-staggered rock burst (Geological tectonics): is the rock burst caused by the shear instability of the fault surrounding rock mass. The rock burst occurs when the mining activity is close to the fault, and the fault suddenly ruptures and dislocates under the influence of mining activities. The destructive intensity is very large when a working face is approaching the fault

Rockburst due to coal seam exploitation techniques: In coal mines the factors such as unreasonable Exploitation techniques and sequence can lead the occurrence of coal burst. After mining, the roof forms a large area of suspension, and the strong pressure acts on the coal pillar, forming a clamping effect on the coal pillar, making it form a high stress concentration. When the pressure exceeds the bearing capacity of coal pillar, the coal burst occurs.

Rock burst critical depth: If the depth of coal seams exploitation is greater than the rockburst critical depth, the rockburst may occur (Li et al., 2016).

\subsubsection{In Chinese Tunnel Excavation}

Along with the development of Chinese modern underground engineering, the several deep tunnels have been constructed in China. the statistics of 1989 showing that Chana had been had 4847 completed railroad tunnels. And by the recent, a number is more than five thousand (Lee et al. 1996). During the excavation of these deep tunnels, some of them have undergone rockburst problem. For examples, Railway tunnels such as: Guancunba, Gaoligongshan, Huangzhushan, Qiuqianping, Puyong, and Qinling tunnels; and Highway tunnels such as: Erlangshan, New Erlangshan, Heishiling, Bamiao, Baitashan, Beiwuyishan, Jinguanshan, Zhongtianshan, and Zhongnanshan tunnel, etc., have undergone rockbursts. (Feng and Zhao 2017). During the excavation of Jinping II Hydropower Station tunnel (around 2,5 Km of depth), rockburst has led to the serious damage of underground workings' equipment, delaying the excavation operation, many fatalities and injuries (Zhang et al., 2012; Feng and Zhao 2017).

\subsection{Rockburst in Australian Mines}

In Australia, mining induced Rock burst is a strong safety and economic threat, especially in Western Australian underground hard rock mines. It has triggered serious damages to deep underground mine working faces and roadways, and contributed to the several deaths and casualties. Due to the development of highly mechanized mining, the western Australian hard rock mines have developed to greater depth, which has led to the increase of in situ stress, then trigger rockbursting. Generally, geological factors, high mining ratio, high in situ stress, are the main causative factors of rockburst in Western Australian mines (Heal et al., 2006).

According to the previous studies, the several cases of rockbursting in western Australian mines have be investigated and reported. For examples: 10 rockburst cases have occurred in Barkers Gold Mine from 2002 to 2003; In Big Bell Gold Mine, 9 bursts cases have occurred from June 1999 to February 2002; The 3 rockbursts cases have happened in Black Swan Nickel Mine between $2^{\text {nd }}$, July 2003 and $5^{\text {th }}$, September 2004; Darlot Gold Mine has undergone 2 bursts cases between $2^{\text {nd }}$, November 2003 and 23 ${ }^{\text {rd }}$, June 2004; From $26^{\text {th }}$, February 2002 to $19^{\text {th }}$, November 2004, the 16 burst cases occurred in Junction Gold Mine; Kanowna Belle Gold Mine has also undergone 5 bursts cases from $12^{\text {th }}$, November 2000 to $11^{\text {th }}$, December 2003 (Heal et al., 2006; Heal, 2010); From July 2001 to October 2001, 4 burst cases have occurred in Strzelecki Mine (Heal, 2010).

\subsection{Rockburst in South African Mines}

In South Africa, Rockburst hazard for safe and efficient exploitation of deep deposits has always been a key problem. South African gold mines are the most severely and frequently affected by rockbursts (Heunis, 1980). At present, the average depth of gold mining in South Africa is more than 1,500 meters, which is the deepest mining depth in world mining industry. In the west, the depth of gold mining has reached 4 kilometers. Frequent rock bursts have been occurring in typical deep mining areas. In 1908, rockburst occurred only 7 times, and 233times in 1918. The 31 deep gold mines in South Africa have undergone 680 rockbursts in 1975, among which 73 people were killed (Xie, 2012). Very dangerous rockburst occurred in South Africa (Witwatersrand mines) in 1960, caused 435 fatalities (Zhou et al. 2016). The lithology of the surrounding rock, high ground stress concentration and the mining depth provide the necessary conditions for rockburst, causing almost all the gold deposits in South Africa to be threatened by rockburst.

The damage of rockburst occurred at Impala platinum mine have shown violent rock ejections, buckling disruption and displacement, shakedown, and falls of ground associated with large distant seismic events. A total of 491 seismic events with have been recorded in 2005 - 2010 in Impala platinum mine (Ledwaba et al., 2012). In general, Rockbursts have led to the serious damage of deep underground mine workings, Infrastructures development, production dilution, delaying the mining operation, many fatalities and injuries. As the depths of gold and platinum mines are planned to increase, and it is noted that the increasing of mining depth leads to the increasing of ground stress, which is one of the factors for rockbursting (Durrheim et al., 2007). 


\subsection{Rockburst in American Mines}

Historically, it is researched that, rock bursts in underground metal mines in North America was first happened at the beginning of $20^{\text {th }}$ century in the Coeur d'Alene Mining District (Lead-Zinc silver mines) and on the Upper Peninsula of Michigan (Copper mines) (Blake, 2017). In Canada, rockburst occurred several times in 1930s in Ontario gold mines (Kirkland Lake and Nickel mines), in 1960s at Red Lake gold mines, and in 1980s at New Brunswick Lead-Zinc mine and Elliot Lake uranium mine (Gibowicz and Kijko, 1994). The factors for rock burst are almost the same in deep mines. Based on influence of multiple coupling geological factors such as geological structure, rock strata formation, physical and mechanical properties of rock mass, depth of exploitation, exploitation method and shape of opening, and in-situ stress state, Some of them or all influence rock burst and other dynamic disasters in deep mines in America.

\subsection{Rockburst in European Mines}

According to the previous research, (the highest production of hard coal in Europe is more pronounced in Germany, Poland, the Czech Republic, and Ukraine, where the intense seismic events and rock bursts are still a strong safety and economic threat in their deep underground mines at depth of thousand meters below the ground surface level (Al Heib, 2017). Some factors for rock burst in Europe include: 1) Fault-staggered rock burst (Geological structure/tectonics): 2) Rockburst due to depth of coal seams exploitation: The depth of European coalmines has reached greater than $1000 \mathrm{~m}$. As positively related, the depth of mining increases with ground stress (Kouame et al., 2017; Liu and Wang, 2018). With this deep coal seam mining and high concentration of ground stress, lead rock bursts occurrence (He et al., 2012; Kaiser and Cai, 2012; Chen et al., 2012; Cai, 2016; Feng et al., 2017; Sengani and Zvarivadza, 2017; Kouame et al., 2017). 3) The nature of the rocks: There are generally very competent rock like sandstone. In the former USSR mines, the rockburst catalogue published by Union Research Institute of Geomechanics and Mine Surveying in 1981, shows a deep description of 73 rockbursts happened in 1973-1980 in 9 Coal mining fields such as: Kizelovsk, Kuznetsk, Vorkuta, Partizan, Bukatchatchinsk and Lipovetsk, Tkibuli-Shaorsk, Shurabsk, Donbass, and Tchelabinsk (Gibowicz and Kijko, 1994).

\subsection{Rockburst in Indian Mines}

In the late $19^{\text {th }}$ century, Rock burst was first occurred in Kolar Gold Mine (India), when the deposits exploitation activity was at 400m of depth (Gibowicz and Kijko, 1994; Saharan, 2004; Konicek et al., 2011). Deep mine at Kolar Gold Field has an history of a hundred years. Kolar Gold Field is known to have three deep mines such as: Champion Reef Mine, Nundydroog Mine, and Mysore Mine. The deepest depth of this mine is $3200 \mathrm{~m}$ from the surface downward (Gibowicz and Kijko, 1994). At greater than $1500 \mathrm{~m}$ of depth, there was huge faults and dykes causing high stress concentrations and the occurrence of rock bursts at Kolar Gold Field. At Champion reef mine, several major rockbursts events happened in between $1500 \mathrm{~m}$ and $3200 \mathrm{~m}$ of depth.
Rock bursts accidents caused serious large-scale damages to deep mine working faces, roadways, and contributed to a big number of casualties (Gibowicz and Kijko, 1994)The factors for rock burst in deep mines at Kolar Gold Field include the influence of geological discontinuities (faults and dykes), rock strata formation, physical and mechanical properties of rock mass, production rate depth of exploitation, geometry of exploitation, as well as the ambient stress field (Srinivasan and Rao, 2017).

\section{MAIN CHARACTERISTICS OF ROCKBURST}

In general, the characteristics of rock burst are the following:

Seismic property: Rockburst are seismic events triggered by deep deposits exploitation in which the rocks fail abruptly and brittlely with high degree of damage after getting strained above their ultimate elasticity. According to Larsson (2004), Kabwe and Wang (2015), a rockburst is the exploitation induced seismic event that affects and cause destruction to excavations in the rock. Obvious sound: The level of sound depends on the level of Rockburst (Wen et al., 2016). Brittleness: During the occurrence of rockburst, rock mass fails in brittle way. Stress property: The occurrence of rock burst is controlled by stress conditions, that is to say, the stress in orebody and surrounding rock where rock burst tend to occur should reach the ultimate stress state. Warningless: Rockburst happens very quickly in a way that is not expected. Dangerous property: A rockburst is hazardous event which involve possible injury, harm, pain and death. Baneful: Rockburst leads to the destruction or serious damage of underground working face, equipment and properties. Hysteresis Quality: A rock burst is not immediate subsequent event after underground rocks' excavation, but it has a retardation quality. After the underground rocks' excavation, in several hours or a long time later, the violent destruction of surrounding rock may take place (Kouame et al., 2017). Continuity property: Rockburst is a continuous event, after the first rockburst occurred, it can continue to happen or develop gradually over a period of time if no control measures taken. Brittness, Strain and elastic property: Rock bursts occurs when rock fails in a brittle way after being strained beyond its elastic limit. Attenuating Property: The initial rockburst at the beginning of excavation, is stronger than the subsequent rockburts (Kouame et al., 2017). Violence: During rockbursting, rock fails violently (Kouame et al., 2017, Vennes and Mitri 2017).

\section{CLASSIFICATION OF ROCKBURST MECHANISM}

According to the different previous studies, they are different classification of rockburst mechanism, however, Strain burst/Face burst, Pillar burst, and Fault slip burst are the main classification of rockburst mechanism (Tang, 2000; Saraham, 2004; Leveillel et al., 2017), as shown in Table 1. 


\begin{tabular}{|l|l|l|l|}
\hline \multicolumn{2}{|c|}{ Table 1. Main classification of rockburst mechanism } \\
\begin{tabular}{|l|l|l|} 
Rockburst \\
Mechanism
\end{tabular} & Triggering Factors & $\begin{array}{c}\text { Characteristics of Rockburst } \\
\text { control measures } \\
\text { taken }\end{array}$ \\
\hline $\begin{array}{l}\text { Strain burst } \\
\text { Face burst }\end{array}$ & $\begin{array}{l}\text { High stress concentration during mine } \\
\text { development (mine openings or roadways } \\
\text { excavation). Accumulation of strain energy in } \\
\text { the rock mass ahead of the face (face burst) }\end{array}$ & $\begin{array}{l}\text { Occur in and at the edge of mine opening (drifts and shafts), } \\
\text { and chambers, especially in brittle rock. It is a hazardous } \\
\text { event. In case of face burst, there is a violent ejection of } \\
\text { material from face to the excavated area. }\end{array}$ & $\begin{array}{c}\text { Rockburst damage and } \\
\text { hazards }\end{array}$ \\
\hline Fault slip burst & $\begin{array}{l}\text { Shear instability of the surrounding rock mass } \\
\text { of Faults, and Dykes }\end{array}$ & $\begin{array}{l}\text { Occur near geological structures such as Faults and Dykes. } \\
\text { Fault suddenly ruptures and dislocates under the influence } \\
\text { of mining activities. It is a hazardous event. }\end{array}$ & $\begin{array}{l}\text { Rockburst damage and } \\
\text { hazards }\end{array}$ \\
\hline Pillar burst & $\begin{array}{l}\text { Excessive mining induced stress on pillars; } \\
\text { High stress; High extraction ratio or large goaf }\end{array}$ & $\begin{array}{l}\text { Failure of Pillar; Pillar spalling; Violent failure of pillar or } \\
\text { hazardous event; Release of large strain energy }\end{array}$ & $\begin{array}{c}\text { Rockburst damage and } \\
\text { hazards }\end{array}$ \\
\hline
\end{tabular}

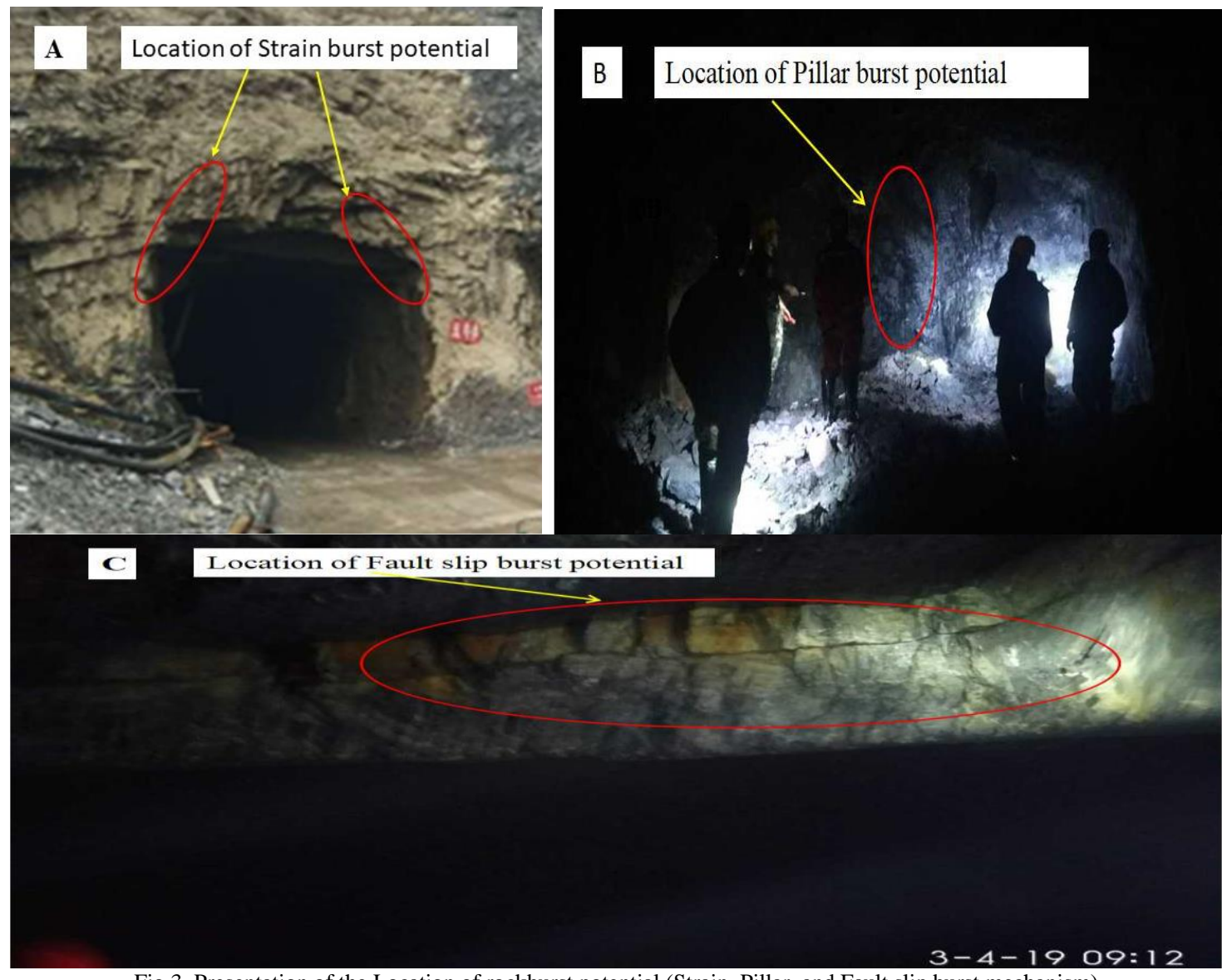

Fig 3. Presentation of the Location of rockburst potential (Strain, Pillar, and Fault slip burst mechanism)

\section{MAIN NEGATIVES EFFECT OF ROCKBURSTING IN DEEP MINES}

Rockburst hazard for safe and efficient economic exploitation of deep deposits has always been a key problem that needs to be solved urgently but has not been solved well in the mining industry. Rockburst hazards are significant safety and economic problems for world mining industry.

After the mine enters deep mining, the geological conditions of resources are further deteriorated, and the ground stress increased significantly, which poses a series of severe challenges to the development, maintenance and control of underground working (Kouame et al., 2017). Rockbursts have caused large-scale damages to the underground mine workings and other underground excavation projects around the world. Below are the main negative effects of rockbursting:
- Loss of live: The occurrence of rockburst leads to the death of people working in deep underground mines.

- Casualties: Rockburst leads to the injuries of people working in deep underground mines.

- Destruction on mining roadway: When rock burst occurs, the roadways are destroyed instantaneously, resulting in serious losses.

- Damage of underground working face: The occurrence of rockburst leads to the interruption of mine working face where the mining operation is being conducted during rockbursting.

- Damage of underground working equipment and properties: The occurrence of rockburst leads to damage of machinery/ excavators, unloaded ores, etc. 
- Increase the cost of mine through rehabilitation: The occurrence of rockburst leads to increase of mining cost by repairing or buying the new machineries, and reconstruction of roadways.

- Temporally stop of mine working: After the occurrence of violent rockburst, the normal mine working cannot continue directly. It takes a period of time for repairing or buying the new machineries, and reconstruction of roadways.

- Delaying the mining operation: By taking a period of time for repairing or buying the new machineries, reconstruction of roadways, and/ or hiring new workers

- to replace the fatalities, these unplanned operations make the mine to be completed in long period of time rather than scheduled.

- Leading to the ore loss and dilution: Rockburst negatively affect regular production of mine.

- Leading to the mine closure: After the occurrence of very violent rockburst, which lead to no way for reoperation, the mine working is decided to permanently stop.

\section{ROCKBURST CONTROL METHODS}

According to the previous studies, rock burst in deep mine can be controlled by destressing techniques. Destress techniques are stress control methods employed in deep underground mine to control rock burst hence ensures the safe and efficient mining. Destressing techniques have been widely used in deep underground mines in South Africa, Canada, USA, China and some of the rest of the world (Tang, 2000). Destressing technique is a method to form a destressed zone in the surrounding rock of excavation space and a stress bearing zone ahead of working face. It has an obvious effect on controlling the stress concentration of surrounding rock and preventing rockburst in the surrounding rock of the stope by the principle of stress transfer.

The ultimate purpose of rockburst research is to predict and control the occurrence of rock burst and relieve its damage to working face, equipments, and miners. Destressing (Stress control method) mining mainly consists of two kinds of methods such as: Regional destressing and local destressing (Dunlop and Gaete, 1997; Scott, 1997; Dubinski and Mutke, 1997; Wu and Zhang, 1997; Blaha, 1990; Glazer, 1997). According to Saraham (2004), Stress control method include Ground Preconditioning, Alternatives mining methods, and Rock support.

Table 3. High stress control methods in deep mines

\begin{tabular}{|c|c|c|c|}
\hline $\begin{array}{l}\text { Destressing } \\
\text { methods }\end{array}$ & Sub methods & Subdivion of Sub methods & Expected Results from the effective application of method \\
\hline \multirow{2}{*}{$\begin{array}{l}\text { Regional } \\
\text { destressing }\end{array}$} & \multirow{2}{*}{$\begin{array}{l}\text { Alternatives } \\
\text { mining } \\
\text { methods }\end{array}$} & $\begin{array}{l}\text { Mining with protective seam/ } \\
\text { Vein }\end{array}$ & $\begin{array}{l}\text { The hard rock mass above or below the orebody is mined first, so that large part of the } \\
\text { orebody falls into the unloaded zone, which reduces the mining stress in a large area of the } \\
\text { orebody. }\end{array}$ \\
\hline & & $\begin{array}{l}\text { Optimization of } \\
\text { development system }\end{array}$ & $\begin{array}{l}\text { Reasonable layout of main roadways and Shafts in combination with mine geological } \\
\text { conditions; Optimizing mining method and chamber structure; The best mining sequence in } \\
\text { the early stage of development. }\end{array}$ \\
\hline \multirow{5}{*}{$\begin{array}{l}\text { Local } \\
\text { destressing }\end{array}$} & \multirow{3}{*}{$\begin{array}{l}\text { Ground } \\
\text { Preconditioni } \\
\text { ng }\end{array}$} & Destress blasting & \multirow{3}{*}{$\begin{array}{l}\text { Reducing the stress in the area where rock burst may occur; Transferring high stress to deep, } \\
\text { away from the roadway and stope; Reducing the strain energy of surrounding rock; } \\
\text { Reducing the mechanical parameters of rock mass, especially the elastic modulus. }\end{array}$} \\
\hline & & Destress drilling & \\
\hline & & Water infusion & \\
\hline & \multirow[t]{2}{*}{$\begin{array}{l}\text { Rock } \\
\text { support }\end{array}$} & Back fill & $\begin{array}{l}\text { Reducing the elastic strain of the hanging wall; Reducing the rate of energy release; Back fill } \\
\text { providing a certain confining pressure to the pillar; The filling body absorbs part of the } \\
\text { energy of mine tremor (mine seismic energy) and prevent stress wave from making pillars to } \\
\text { fail }\end{array}$ \\
\hline & & $\begin{array}{l}\text { Rock reinforcement (shotcrete, } \\
\text { bolting, wiremesh, steel } \\
\text { support) }\end{array}$ & $\begin{array}{l}\text { Supporting and reinforcing the fractured rock mass, and rock mass tending to fail. It plays a } \\
\text { great role of retaining and holding the fractured or discontinued rock mass }\end{array}$ \\
\hline
\end{tabular}

\section{SUMMARY AND CONCLUSION}

From this review, the Authors have found that after the mine enters deep mining, the geological conditions of resources are further deteriorated, and the ground stress increased significantly, which poses a series of severe challenges to the development, maintenance and control of underground working. Rockburst is among these challenges which is seismic events triggered by deep deposits exploitation in which the rocks fail abruptly and brittlely with high degree of damage after getting strained above their ultimate elasticity.

In general, the factors for rockbursting are almost the same in deep mines and other underground excavation projects, with special difference of local geological condition. It can be caused by a single factor where rockburst is caused by one factor, or multiple factors where rockburst is caused by more than one factors.These include the influence of multiple coupling geological factors such as geological structure, rock strata formation, physical and mechanical properties of rock mass, depth of exploitation, exploitation method and shape of opening, Blasting operation, ground water, and ground or insitu stress state, and extraction rate. One or a combination of some of them can contribute to the occurrence of rock burst and other dynamic disasters in deep mines and other underground excavation projects.

It is also reviewed that the main properties to characterise the rockburst include: Obvious sound, Seismic property, Suddenness, Violence or Dangerous, Baneful, Hysteresis property, Continuous event quality, Attenuating property, Brittleness, Stress, Strain and elastic property. According to the different previous studies, they are different classification of rockburst mechanism, however, Strain burst/ face burst, Pillar burst, and Fault slip burst are the main classification of rockburst mechanism. The destressing methods to control 
rockburst were reviewed as: Alternatives mining methods, Ground Preconditioning (Destress blasting, Destress drilling, Water infusion), and Rock support and Rock reinforcement

From this review, it is clearly seen that, a rock burst is a significant safety and economic problem in deep underground mines and other underground excavation projects around the world. Rock burst hazard for safe and efficient exploitation of deep deposits has always been a key problem that needs to be solved urgently but has not been solved well in the mining industry. From this point of view, the authors recommend the underground engineering engineers and researchers such as Mining engineers, Seismologists, Geotechnical engineers, Rock mechanics engineers, Engineering geologists and other concerned researchers to rethink and rethink, by conducting a thorough study on rock burst control measures to enhance the safety and efficiency of deep underground deposits exploitation and other underground excavation projects.

\section{ACKNOWLEDGEMENT}

Special thanks to editors and anonymous reviewers for their hard work and valuable comments on this article.

\section{REFERENCES}

[1] Li X, Murwanashyaka E (2019) Optimization Study of Stope Structura Parameters in High Stress Zone of Deep Deposit. International Journa of Emerging Technologies and Innovative Research 6 (6): 360-368. DOI: http://doi.one/10.1729/Journal.22351

[2] SUN S.G, GONG Z.Q, WEI S.Y (2017) The Study of Rock Burst Induced by Underground Mining Excavation. Proceedings of the $2^{\text {nd }}$ International Conference on Environmental Science and Energy Engineering (ICESEE 2017), Beijing, China, pp. 25-28.

[3] Liu, J.-P \& Feng, X.-T \& Van Aswegen, Gerrie \& Blake, W. \& Srinivasan, C. \& Rao, M.V.M.S. \& Zembaty, Zbigniew. (2017). Case Histories of Rockbursts at Metal Mines. 10.1016/B978-0-12-805054 5.00003-2

4] Kouame K J A, Jiang F, Zhu S, Feng Y (2017) OVERVIEW OF ROCK BURST RESEARCH IN CHINA AND ITS APPLICATION IN IVORY COAST. International Journal of GEOMATE.12(29): 2042011. DOI: http://dx.doi.org/10.21660/2017.29.67564

[5] Liu X, Wang E (2018) Study on characteristics of EMR signals induced from fracture of rock samples and their application in rockburs prediction in copper mine. J. Geophys. Eng 15:909-920. https://doi.org/10.1088/1742-2140/aaa3ce

[6] He M, Xia H, Jia X, Gong W, Zhao F, Liang K (2012) Studies on classification, criteria and control of rock bursts. Journal of Rock Mechanics and Geotechnical Engineering 4 (2): 97-114. Doi: 10.3724/SP.J.1235.2012.00097

[7] Kaiser PK, Cai M (2012) Design of rock support system under rockburst condition. Journal of Rock Mechanics and Geotechnical Engineering 4 (3): 215-227. Doi: 10.3724/SP.J.1235.2012.00215

[8] CHEN G, DOU L, XU X (2012) Research on prevention of rock burst with relieving shot in roof. Procedia Engineering (45) 904 - 909. doi: 10.1016/j.proeng.2012.08.257

[9] Cai MF (2016) Prediction and prevention of rockburst in metal mines A case study of Sanshandao gold mine. Journal of Rock Mechanics and Geotechnical Engineering http://dx.doi.org/10.1016/j.jrmge.2015.11.002

[10] Feng X.T, Liu J, Chen B, Xiao Y, Feng G, Zhang F (2017) Monitoring, Warning, and Control of Rockburst in Deep Metal Mines. Engineering 3: 538-545. http://dx.doi.org/10.1016/J.ENG.2017.04.013

[11] Sengani F, Zvarivadza T (2017) Review of pre-conditioning practice in mechanized deep to ultra-deep level gold mining. Conference Paper 113-127.

[12] Liu JP, Xu SD, Li YH, Lei G (2019) Analysis of Rock Mass Stability Based on Mining Induced Seismicity: A Case Study at the Hongtoushan Copper Mine in China. Rock Mechanics and Rock Engineering 52:265-276. https://doi.org/10.1007/s00603-018-1541-y
[13] Liu QQ, Liu ZF, Shao YJ, Zhou HD, Liu N, Huang KX, Zhang JD, Wang C (2018) Major and Trace Element Geochemistry of Pyrite and Pyrrhotite from Stratiform and Lamellar Orebodies: Implications for the Ore Genesis of the Dongguashan Copper (Gold) Deposit, Eastern China. Minerals 2018, 8, 380 .

[14] Wen Z, Wang X, Tan Y, Zhang H, Huang W, Li Q (2016) A Study of Rockburst Hazard Evaluation Method in Coal Mine. Shock and Vibration. http://dx.doi.org/10.1155/2016/8740868

[15] Shao YJ, Liu ZF, Wei HT, Wang C (2016) Rock forming mechanism of Qingshanjiao intrusion in Dongguashan copper (gold) deposit, Tongling area, Anhui province, China. Transactions of Nonferrous Metals Society of China 26(9): 2449-2461. https://doi.org/10.1016/S1003-6326(16)64365-0

[16] Zeng QD, Wang ZC, He HY, Wang YB, Zhang S, Liu JM (2014) Multiple isotope composition $(\mathrm{S}, \mathrm{Pb}, \mathrm{H}, \mathrm{O}, \mathrm{He}$, and $\mathrm{Ar}$ ) and genetic implications for gold deposits in the Jiapigou gold belt, Northeast China. Miner Deposita 49:145-164. doi 10.1007/s00126-013-0475-2

[17] Meng D, Wang N, Ai JC, Zhang G, Liu XJ (2016) Distribution and assessment of residual mercury from gold mining in Changbai Mountain Range Northeastern China. IOP Conf. Series: Earth and Environmental Science 39012007 doi:10.1088/1755 $1315 / 39 / 1 / 012007$

[18] Liu L, Yang XY, Santosh M, Wang GJ, Aulbach S (2017) Initial gold enrichment within a Neoarchean granite-greenstone belt: Evidence from ore bearing and ore barren samples in the Jiapigou deposits, NE China. Ore Geology Reviews 81:211-229. https://doi.org/10.1016/j.oregeorev.2016.09.037

[19] Yang S, Blum N, Rahders E, Zhenru Z (1998) The nature of invisible gold in sulfides from Xiangxi Au-Sb-W ore deposit in northwestern Hunan, People's Republic China. The Canadian Mineralogist 36 (5): 1361-1372.

[20] Chen YJ, Chen HY, Zaw K, Pirajno F, Zhang ZJ (2007) Geodynamic settings and tectonic model of skarn gold deposits in China: An overview. Ore Geology Reviews 31: 139-169. doi: 10.1016/j.oregeorev.2005.01.001

[21] ZHANG CQ, LIU H, WANG DH, CHEN YC, RUI ZY, LOU DB, WU Y, JIA FD, CHEN ZH, MENG XY (2015) A Preliminary Review on the Metallogeny of Pb-Zn Deposits in China. ACTA GEOLOGICA SINICA (English Edition) 89 (4):1333-1358

[22] Yuan RM, Ma FS, Deng QH, Cunningham D, Zhao HJ (2013) Vertical shaft collapse at the Jinchuan Nickel Mine, Gansu Province, China: analysis of contributing factors and causal mechanisms. Environ Earth Sci 69:21-28. DOI 10.1007/s12665-012-1930-6

[23] Yang ZQ (2017) Key progress on the filling mining of deep resources in Jinchuan Nickel Deposit. Paste 413-425. https://papers.acg.uwa.edu.au/p/1752 46 Yang/

[24] Fan HR, Hu FF, Zhai MG, Jin CW (2006) Fluid evolution in the Rushan lode gold deposit of Jiaodong Peninsula, eastern China. Journa of Geochemical Exploration $89 \quad(1-3): 161-164$ https://doi.org/10.1016/i.gexplo.2005.11.057

[25] Larsson K (2004) Mining Induced Seismicity in Sweden. Master Dissertation, Luleå University of Technology.

[26] Kabwe E, Wang Y (2015) Review on Rockburst Theory and Types of Rock Support in Rockburst Prone Mines. Open Journal of Safety Science and Technology 5:104-121. http://dx.doi.org/10.4236/ojsst.2015.54013

[27] Vennes I, Mitri H (2017) Geomechanical effects of stress shadow created by large-scale destress blasting. Journal of Rock Mechanics and Geotechnical Engineering 9: 1085-1093.

[28] Mao ZY, Zhang XB (1996) Study on the rock burst treatment in deep mining. Coal Mining 3:33-35. (in Chinese).

[29] Shi Q, Pan Y, Li Y (2005) The typical Cases and Analysis of Rockburst in China. Coal Mining Technology 10 (2):13-17. (in Chinese with English abstract).

[30] Ma Y, Liu C, Wu F, Li X (2018) Rockburst Characteristics and Mechanisms during Steeply Inclined Thin Veins Mining: A Case Study in Zhazixi Antimony Mine, China. Shock and Vibration. https://doi.org/10.1155/2018/3786047

[31] ZHANG X. WANG J (2007) Research on the Mechanism and Prevention of Rockburst at the Yinxin Gold Mine. J China Univ Mining \& Technol 17(4): 0541-0545.

[32] Zhou J, Li X, Mitri H (2016) Classification of Rockburst in Underground Projects: Comparison of Ten Supervised Learning Methods. J. Comput. Civ. Eng 30(5): 1-19. DOI: 10.1061/(ASCE)CP.1943-5487.0000553. 
[33] Dou, L \& Lu, C \&Li, Z. H\& Al Heib, M. (2017). Case Histories of Rockburst at Coal Mines. https://doi.org/10.1016/B978-0-12-8050545.00004-4

[34] Li X, Wang E, Li Z, Liu Z, Song D, Qiu L (2016) Rock Burst Monitoring by Integrated Microseismic and Electromagnetic Radiation Methods. Rock Mech Rock Eng 49:4393-4406. DOI 10.1007/s00603016-1037-6

[35] Lee CF, Wang SJ, Yang ZF (1996) Geotechnical aspects of rock tunnelling in China. Tunn Undergr Sp Tech 11(4):445-454.

[36] Feng, X. T \& Zhao, Z \& Panthi K. K (2017) Case Histories of Rockburst at Tunnels. https://doi.org/10.1016/B978-0-12-8050545.00002-0

[37] Zhang CQ, Feng XT, Zhou H, Qiu SL, Wu WP (2012) Case Histories of Four Extremely Intense Rockbursts in Deep Tunnels. Rock Mech Rock Eng 45:275-288. DOI 10.1007/s00603-011-0218-6

[38] Heal D, Potvin Y, Hudyma M (2006) Evaluating Rockburst Damage Potential in Underground Mining. ARMA/USRMS $06-1020$

[39] Heal D P, 2010. Observations and Analysis of Incidences of Rockburst Damage in Underground Mines. PhD Dissertation, University of Western Australia.

[40] Heunis R (1980) The development of rock-burst control strategies for South Africa gold mines. J. S. Afr. Ins. Metall 139-149.

[41] Xie Y (2012) Deep Metal Mine relief mining. Master thesis (in Chinese with English abstract)

[42] Ledwaba LS, Scheepers J, Durrheim RJ, Spottiswoode SM (2012) Rockburst Damage Mechanism at Impala Platinum Mine. The Southern African Institute of Mining and Metallurgy, Southern Hemisphere International Rock Mechanics Symposium SHIRMS 367- 386

[43] Durrheim RJ, Cichowicz A, Ebrahim-Trollope R, Essrich F, Goldbach O, Linzer LM, Spottiswoode SM, Stankiewicz T. Deep Mining $07-$ Y. Potvin (ed) $\odot 2007$ Australian Centre for Geomechanics, Perth, ISBN 978-0-9804185-2-1 Deep Mining 07, Perth, Australia 249 https://papers.acg.uwa.edu.au/p/71118 Durrheim/
[44] Gibowicz S J, Kijko A (1994) An Introduction to Mining Seismology. Academic press, Oval Road, Londan

[45] Saharan MR (2004) DYNAMIC MODELLING OF ROCK FRACTURING BY DESTRESS BLASTING. PHD Dissertation, McGill University.

[46] Konicek P, Saharan M R, Mitri H. (2011) Destress Blasting in Coal Mining - State-of-the-Art Review. First International Symposium on Mine Safety Science and Engineering, Procedia Engineering, 26: 179 194.

[47] Tang B (2000) Rockburst Control Using Destress Blasting. PHD Dissertation, McGill University.

[48] Leveille1 P, Sepehril M, Apell DB (2017) Rockbursting Potential of Kimberlite: A Case Study of Diavik Diamond Mine. Rock Mech Rock Eng 50:3223-3231. https://doi.org/10.1007/s00603-017-1294-z

49] Dunlop R, Gaete S (1997) Controlling induced seismicity at E Teniente Mine: The Sub 6 sector case history. Rockbursts and seismicity in mines, Gibowicz and Lasocki eds. Rotterdam: Balkema, 233-236.

[50] Scott D F, Williams T J, Friedel M J (1997) Investigation of a rockburst site, Sunshine Mine. Rockbursts and seismicity in mines, Gibowicz and Lasocki eds. Rotterdam: Balkema, 311-315.

[51] Dubinski J, Mutke G (1997) Characteristics of near-field peak velocity in the Upper Sliesian Coal Mines. Rockbursts and seismicity in mines, Gibowicz and Lasocki eds. Rotterdam: Balkema, 343-347.

[52] Wu Y, Zhang W (1997) Prevention of rockbursts in coal mines in China. Rockbursts and seismicity in mines, Gibowicz and Lasocki eds. Rotterdam: Balkema, 361-365

[53] Blaha F (1990) Some principles of rock mass failure in the case of rock bursts. Mechanics of Joint and Faulted Rock, Rossmanith ed. Rotterdam: Balkema, 757-762

[54] Glazer S N (1997) Applied mine seismology: A Vaal Reefs prospective. Rockbursts and seismicity in mines, Gibowicz and Lasocki eds. Rotterdam: Balkema, 227-231. 